\title{
The Evaluation of Cardiovascular Endurance Test for Male Cadet Officers
}

\author{
Mohar Kassim $^{1}$ \& Rahmat Sholihin Mokhtar ${ }^{2}$ \\ ${ }^{1}$ Centre for Coaching Science, National Defence University of Malaysia, Malaysia \\ Correspondence: Mohar Kassim, Centre for Coaching Science, National Defence University of Malaysia, Kem \\ Perdana Sg. Besi, 57000 Kuala Lumpur, Malaysia. E-mail: mohar@upnm.edu.my
}

Received: June 26, 2015

Accepted: August 13, 2015

Online Published: December 24, 2015

doi:10.5539/mas.v10n2p11

URL: http://dx.doi.org/10.5539/mas.v10n2p11

\begin{abstract}
The aim of this research is to measure a cardiovascular endurance performence for 18 year old male cadet officers. The descriptive quantitative research is carried out by experimental observation by using a $2.4 \mathrm{~km}$ Run Test as the instrument. A total of 120 respondents is selected by random in the Foundation Programme NDUM Session 2013/2014 in the research. Descriptive Statistics is used to explain the characteristics of the sample. The analysis of data used is mean, median and standard deviation. The findings showed the level of cardiovascular endurance fitness for the male cadet officers in the Foundation level in NDUM is at a very satisfactory level ( $\mathrm{M}=10.86, \mathrm{SD}=0.91$ ) with the normal percentile norm and recorded time 11.13 minutes that is located at the 50th percentile and above. The fitness norm is produced by using guidelines layed out by Cooper (2007). Therefore, the norms that has been produced is recommended to be utilized widely to measure the level of cardiovascular endurance fitness for an 18 years old male.
\end{abstract}

Keywords: $2.4 \mathrm{~km}$ run test, cadet officer, cardiovascular endurance fitness, NDUM, physical fitness norm

\section{Introduction}

Fitness is defined as the condition that allows an individual to lead a perfect life and to deliver his tasks efficiently, and in turn produces useful contributions and services. Fitness consists of five components, which are physical, emotional, spiritual, intellectual, and social fitness. All the five components of fitness need to be adjusted and balanced in order for an individual to get on with his daily life.

Physical fitness is a component that constitutes total fitness that is constantly being used in acting or in any form of action. Physical fitness is defined as the ability of a person doing a daily routine without fatigue by using maximum energy and still have the extra energy to use during free time or in emergencies. This is supported by Penny and Clarke (2005) that points out that physical fitness is defined as the ability to carry out daily routine efficiently and with fitness without feeling over tiring while having sufficient energy to carry out any type of recreation.

There are five components of physical fitness; which are muscle endurance, cardiovascular endurance, muscle strength, flexibility, and body composition. Among these 5 components, only one component chosen to be studied in this study through the production of cardiovascular endurance norm. The reason for this was because muscle endurance is a component that dominates the daily fitness of an individual. Whether or not an individual is fit, his performance would be measured based on his level of cardiovascular endurance. Kassim, M. \& Isa, M.I (2015), noted that the athletes are engaged in a process of learning, which involves important aspects interpersonal and intrapersonal skills. This is supported by Kassim, M \& Berahim, M.(2015), a conducive learning environment is also important, as well as giving them a reward if they achieve excellence.

Physical fitness can be further classified into health-based and motor-based fitness (Glassman, 2002; Haskell et al., 2007). Haskell et al. (2007) and Glassman (2002) described health-based fitness such as cardiovasuclar endurance, muscular endurance, muscle strength, softness of muscles, and the composition of body that covers the aspect that is related to the function of physiology and psychology; believed to give the individual protection from the threat of hypokinetic diseases; such as heart diseases, obesity, and muscular disease. On the other hand, motor-based fitness refers to the muscle potential and the ability of an individual to carry out physical activity in 
terms of balance, agility, speed, power, reaction time and coordination. In addition, physical training is defined as training required to prepare players' respiratory, energy, and muscular systems physiologically from aerobic, anaerobic, and strength perspectives (Kassim,M \& Ali, N.C.R, 2015). This is supported by Kassim, M; Azmir, H \& Mokhtar, S.R (2014), fitness is defined as the condition that allows an individual to lead a perfect life and to deliver his tasks efficiently, and in turn produces useful contributions and services. fitness consists of five components, which are physical, emotional, spiritual, intellectual, and social fitnessConsequently, according to Kassim, M; Ahmad, S.K.S \& Muda, B.B (2016) cardiovascular endurance is a most important component in the human physiology. The primary element of health-based fitness is the cardiovascular endurance which means the ability of the heart and lungs to provide oxygenated blood to the working muscle tissues for them to use the oxygen to generate energy that is needed for any action to be carried out (Zupan, 2012). He further pointed out that the level of cardiovascular endurance can be assessed by a physical test, for example a $2.4 \mathrm{~km}$ Run Test. The time recorded in the running test is compared to the $2.4 \mathrm{~km}$ run test norms. The $2.4 \mathrm{~km}$ Run Test norms elicit the level of cardiovascular endurance fitness of a person by comparing the recorded time with the norms.

\subsection{Background}

Fitness tests are often referred as an appraisal for the level of fitness or a measure in determining the health status and physical fitness of an individual. In every test, there are norms that has been predetermined that act as the control of the tests and it is used by trainers to assess athletes by carrying out the tests aforementioned. The norms or guidelines help in assessing the level of fitness and detecting the efficacy of the fitness training carried out (Quinn, 2012). According to Quinn (2012), norms in a particular fitness test constitute motivation element to help an individual to carry out better physical workout.

The fitness norm is referred as the guideline or range of marks that has been formulated after the process of calculation and analysis for a particular fitness test (Dove Edwin, 2009). A research on physical fitness norm; conducted by Keating (2003) who investigated the fitness test program carried out for teenagers in United State uncovers the efficacy of the program through test battery that constitutes the fitness norms. It has proven that the test enhances the lifestyle quality related to health. Keating (2003) later concluded that trainers should choose and develop training programs that are already available to make them more efficient and dynamic. Kassim, M \& Mokhtar, S.R. (2015), determined that physical activities can contribute to physical fitness. Discipline and methods of training must be strictly followed to produce an expected result to achieve physical fitness by carrying out physical activities

The cardiovascular fitness norm for a $2.4 \mathrm{~km}$ Run Test used to be referred based on the American College of Sports Medicine standard (ACSM, 1999). The norm was produced by using the same procedure but in different environmental condition as compared to our country, Malaysia. This will inevitably produce variation in results and will evoke difficulty in determining the true level of fitness of an individual among Malaysians. Until today, there is no local fitness norm produced to test the level of physical fitness of an 18 year old Malaysians. Hence, the researcher took the initiative to carry out this research so that the local cardiovascular endurance fitness norm is produced.

Physical fitness is the most important aspect to be paid attention to by all cadet officers of the National Defence University of Malaysia. This component of fitness is required because cadet officers will be absorbed into permanent position in the Malaysian Armed Forces, which require their staff to be at an optimum fitness level (UPNM, 2010).

As the first research of its kind in Malaysia, the researcher focused on the production of cardiovascular endurance fitness norms for an 18 year old males. The cardiovascular endurance fitness norms are produced from the analyzed data from the $2.4 \mathrm{~km}$ Run Test results which is used as the instrument in this research.

\subsection{Objective}

The objective of this research is to create a cardiovascular endurance fitness norm for an 18 years old male cadet officers that uses $2.4 \mathrm{~km}$ Run Test which was introduced by The Cooper Institute. Besides that, the purpose of this research is to assess the level of cardiovascular fitness for individuals of an 18 years old male.

\section{Method}

The method of this research is by experimental observation. The design of this research is therefore due to utilization of the available instrument that was introduced by The Cooper Institute. The Statistical Package for Social Sciences (SPSS) software version 20 was used to calculate and translate the data by descriptive in the descriptive statistical analysis. The findings has enable the researcher to calculate the percentile, mean and 
standard deviation for the overall result in this research.

NDUM students consist of cadet officers and public students. Cadet students or more precisely known as cadet officers study in NDUM with military orientation because they will be absorbed into ATM right after graduation. Public students are not bound to the same rules and regulation imposed on cadet officers. However, all NDUM students are obliged to participate in trainings as according to the curriculum. The objective of the trainings is to produce graduates that possess not only great erudition, but also strong physicals to endure the working world.

The sample of the research is the respondents that constitute the male cadet aged 18 years old from the NDUM Foundation Program Session 2013/2014. A total of 120 male cadet officers were chosen to perform the $2.4 \mathrm{~km}$ Fitness Run Test representing 30 percent from the total male cadet officers of the NDUM Foundation Program Session 2013/2014 (UPNM, 2014).

\subsection{Instrument of Research}

To measure the level of physical fitness in a study, there must be a test suitable that matches the study. The physical fitness test that is carried out is considered as the instrument of study. The instrument used in physical fitness study must have high validity and reliability in order for the result to be indisputable (Ahmad, 2004; Bird, 2014). In this study, the instrument chosen is a $2.4 \mathrm{~km}$ Run Test that was developed by The Cooper Institute, (Gregory \& Charles, 2012; The Cooper Institute, 2007). The $2.4 \mathrm{~km}$ Run Test has high a reliability where r $=0.92$, (ACSM, 1999; Johnson \& Nelson, 1986), and r=0.86, (John et al., 1999).

\section{Results}

The respondents of 120 male cadet officers from the NDUM Foundation Program were chosen by random for this research. The descriptive statistical analysis show that the mean score and the standard deviation for all the respondents involved in the $2.4 \mathrm{~km}$ Run Test $(\mathrm{M}=10.86, \mathrm{SD}=0.91)$.

Table 1. Descriptive Statistic on respondents' 2.4 km Run Test scores

\begin{tabular}{rr}
\hline \multicolumn{2}{c}{18 Years Old Male Cadet } \\
\hline Descriptive Statistics & Test score \\
\hline Minimum & 9.17 \\
Maximum & 13.13 \\
Mean & 10.8646 \\
Median & 11.1350 \\
Std. Deviation & 0.91960 \\
Skewness & -0.036 \\
18 Years old & \\
$\mathrm{N}$ & 120 \\
\hline
\end{tabular}

Table 1 shows the statistical descriptive $2.4 \mathrm{~km}$ Run Test score for the male cadet student in this research. The minimum recorded time is 9:17 minutes and maximum is 13.13 minutes while the median is 11.13 minutes. The statistical skewness is -0.36 leads to a normal shaped distribution.

Table 2. Percentile Norm for 2.4 km Run Test

\begin{tabular}{ccc}
\hline Percentile & $\begin{array}{c}\text { 18 Years Old Male } \\
\text { (mm:ss) }\end{array}$ & Total \\
\hline 95 & $9: 51$ & 6 \\
90 & $9: 55$ & 6 \\
75 & $10: 03$ & 21 \\
50 & $11: 13$ & 27 \\
25 & $11: 45$ & 33 \\
10 & $12: 11$ & 15 \\
5 & $12: 34$ & 12 \\
N & & 120 \\
\hline
\end{tabular}

Note. $(\mathrm{mm}: \mathrm{ss})=($ minutes $:$ seconds $) ; \mathrm{N}=$ total. 
Table 2 shows the recorded time 11.13 minutes and below for the $2.4 \mathrm{~km}$ Run Test that is located on the 50th percentile and above. This means that about 60 male officers from the total sample of 120, passed the 50th percentile. Only 12 male cadets were recorded to be in the lowest precentile which is in the 5th with the recorded time 12:34 minutes and above. The highest percentile is located on the 95th with the recorded time 9:51 minutes and below.

Table 3. Cardiovascular Endurance Physical Fitness Norm for 18 Years old NDUM Foundation Programme Male Cadet Officers

\begin{tabular}{rrr}
\hline Category & Score & Duration (mm:ss) \\
\hline Excellent & 5 & $<9: 40$ \\
Very Good & 4 & $9: 41-10: 40$ \\
Good & 3 & $10: 41-11: 30$ \\
Satisfactory & 2 & $11: 31-12: 24$ \\
Poor & 1 & $12: 25>$ \\
\hline
\end{tabular}

Note. $(\mathrm{mm}: \mathrm{ss})=($ minutes:seconds).

Table 3 shows the norms produced based on the 2.4 Run Test results. There are 5 categories that are classified in the grade production of a fitness norm which are; Excellent (5), Very Good (4), Good (3), Satisfactory (2), and Poor (1). According to (Ahmad, 2004), grading a test in the production of norms enables different levels of potential in a particular group according to the abilities of each one of the individuals. Every category of accomplishment states the scores achieved starting from the highest score which is 5 to 1 , which 1 indicates the lowest score. Such norms also being used by the National Physical Fitness Award (NAPFA) Singapore (MINDEF, 2015). From the table, the highest achievement which is Excellent with the score of 5 starts from 9:40 minutes and below, the next level is Very Good with the scores of 4 is from 9:41 to 10:40 minutes, the Good level with the score of 3 is from 10:41 to 11:31 minutes, and the Satisfactory level with the score of 2 is from 11:31 to 12:24 minutes and lastly, the Poor level with the score of 1 is from 12:25 minutes and above.

Table 4. Comparison of the Cardiovascular Endurance Physical Fitness Norms of an 18 Years Old Male

\begin{tabular}{rrrrr}
\hline & & & Duration (mm:ss) \\
\cline { 3 - 5 } Category & Score & Mohar (2015) & NAPFA (2014) & Cooper (1982) (13-19 years old) \\
Very Good & 4 & $9: 41-10: 40$ & $10: 21-11: 00$ & $9: 41-10: 48$ \\
Good & 3 & $10: 41-11: 30$ & $11: 01-11: 40$ & $10: 49-12: 10$ \\
Satisfactory & 2 & $11: 31-12: 24$ & $11: 41-12: 30$ & $12: 11-15: 30$ \\
Poor & 1 & $12: 25>$ & $12: 31-13: 20$ & $15: 30>$ \\
\hline
\end{tabular}

Note. $(\mathrm{mm}: \mathrm{ss})=($ minutes:seconds).

Table 4 shows the comparison of norms from a few studies that were conducted using the $2.4 \mathrm{~km}$ Run Test. Through the comparisons, the Excellent category (5) in the NAPFA Programme is 10:20 and below, and in the Cooper study (1982) is 9:40 minutes and below. NAPFA Progamme recorded the Poor level (1) from 12:31 to 13:20 minutes while Cooper recorded the poor level starting from 15:30 minutes and above.

\section{Discussion and Implication}

The cardiovascular endurance physical fitness through the $2.4 \mathrm{~km}$ Run Test for an 18 year old male cadet officers from the NDUM Foundation Program based on the norms produced guided by the procedure and administration that is outlined by (The Cooper Institute, 2007) is very satisfactory. From the analysis, the cadet officers passed with at least achieving the score of 1 in the run test. The result of this research almost resembles the result that was conducted in the study by Cooper (1982). Many researchers opined that physical activity and physical fitness are directly related. However, facts revealed that both of them has their own respective characteristics. Physical activities can contribute to physical fitness, however the relationship between both of them is not as expected if disciplines and methods of training is not followed properly.

Analysis was made through the norms produced. There are not much differences between the fitness norms among the 18 year old NDUM Foundation Program male cadet that has been produced in the research and the fitness norms showed in the NAPFA Program and Cooper (1982). The findings has also shown that the level of 
fitness between countries differs. The factors in the differences may be due to the environment and condition differences in a particular country besides the geography and people.

\section{Conclusion}

Overall, the findings of this research which is the cardiovascular endurance fitness norm for an 18 years old NDUM Foundation Program male cadet officers can be used as a guideline to measure the overall level of fitness for the reference of other group of people. With the production of the norms, the level of cardiovascular fitness norm for an 18 years old male can be assessed through the $2.4 \mathrm{~km}$ Run Test. The norms measures and determines the level of fitness accurately when the test is done. Generally, the fitness norm benefits a lot of people especially the teenagers that falls into the age category of interest. Among the benefits are not only to know the level of fitness but also acts as the motivation to enhance a better lifestyle that is healthy and safe.

It is hoped that the outcome of this research will have positive impacts on several parties that were involved in the management of sports team particularly for trainers. Therefore, it is crucial to have full understanding in the efficient training system to produce quality and planned goals for any team or athletes. It is consistent with the research conducted by Silverman, Keating and Philips (2008) that proposed that an efficient training system using fitness test procedure should have high potential to make it as an interesting experience to attract people involved especially youths.

Greater importance should be placed on the review of the coach education programme to ensure the effectiveness of the programme in producing competent coaches and quality players in future (Kassim, 2008). In addition, Kassim (2008) stated that training are elements of the coaching process and become important indicators for the hard work undertaken by the athletes to enhance performance.

The findings of this research could be patented and used as the proprietary of the National University of Defense Malaysia and also used as a fitness guideline to produce fitness norms for every age and gender in Malaysia.

\section{Acknowledgement}

Special appreciation and thank to Research and Innovation Division, National Defence University of Malaysia and Centre for Coaching Science, National Defence University of Malaysia and all those who make this research a reality.

\section{Reference}

ACSM. (1999). ACSM's fitness book. United States of America: United States of America: Human Kinetics.

Ahmad, H. (2004). Pengukuran Kecergasan Motor. Tanjung Malim: Quantum Books.

Bird, S. (2014). The role of fitness testing \& selecting and using fitness test. Sportsheet.

Cooper Institute for Aerobics Research. (2007). FITNESSGRAM test administration manual (4th ed.). Champains IL: Human Kinetics.

Cooper, K. H. (1982). The Aerobic Program for Total Well-Being. New York: Bantam Books.

Dove Edwin, F. H. (2009). The fitness parameters of 14-17 year old children in Sierra Lione. Michigan: ProQuest Dissertations \& Theses (PQDT).

Glassman, G. (2002). What Is Fitness and Who Is Fit? THE CrossFit Journal, 1-11.

Gregory, G. H., \& Charles, D. (2012). Laboratory Manual for Exercise Physiology. Champaign, IL: Human Kinetics.

Haskell, W., Lee, I., Pate, R., Powell, K., Stewen, N., Blair, P., \& Bauman, A. (2007). Physical Activity and Public Health, Updated Recommendation for Adults. American College of Sports Medicine and the American Heart Association, 1081-1093.

John, A. G., Joseph, A. N., \& Campagna, P. D. (1999). The Prediction of V• O2max: A Comparison of 7 Indirect Tests of Aerobic Power. Journal of Strength and Conditioning Research, 346-252.

Kassim, M. (2008). A Qualitative Study of the Relationship Between the Knowledge and Behaviour of Coaches in two Football Academies in Malaysia.Unpublished doctoral thesis, Loughborough University, UK.

Kassim, M. \& Isa, M.I (2015). The Importance of Pscychology Factors for male hockey goalkeeper. Australian Journal of Basic and Applied Science. ISSN: 1991-8178.

Kassim, M \& Berahim, M.(2015). Footbal training Development Programme under -15 years old State Level. 
Australian Journal of Basic and Applied Science. EISSN: 2309-8414.

Kassim,M \& Ali, N.C.R (2015). An Effective Coaching Through "Coaching Model". Journal of Scientific Research \& Development. Vol:2. Special Issues 9. ISSN 1115-7569.

Kassim, M \& Rustam. S (2015). Inculcation of values in co-curricular activities from virtues module. Journal of Scientific Research \& Development. Vol:2. Special Issues 9. ISSN 1115-7569.

Kassim, M \& Mokhtar, S.R. (2015). Test and Measurement of cardiovascular fitness for female cadet officers. Journal of Scientific Research \& Development. Vol:2. Special Issues 8. ISSN 1115-7569.

Kassim, M; Ahmad, S.K.S \& Muda, B.B (2016). Konsep Latihan Dalam Sukan. Pekan Ilmu Publication Sdn. Bhd. Kuala Lumpur.

Kassim, M; Azmir, H \& Mokhtar, S.R (2014). The Development of portable application software for cardiovascular fitness norms of NDUM cadet students. Proceedings International Conference Sport Science, Dubai.

Keating. (2003). Examine the current youth fitness test program in the United State. The Fitness-gram, President's Challenge and the YMCA youth the programs.

MINDEF. (2015). Ministry of Defense, Singapore. Retrieved from http:// ons/eBooks/More_eBooks/MySonTheNSMan_whatParentsShldKnowabtNS_29may08.pdf

Penney, D., \& Clarke, G. (2005). Inclusion in Sport Education. In D. Penney, G. Clarke, M. Quill, \& G. D. Kinchin (Eds.), Sport Education in Physical Education: Research Based Practice (pp. 41-54). Taylor \& Francis.

Quinn, E. (2012). What Is A Fitness Test. Retrieved January 14, 2013, from http://sportsmedicine.about.com/od/fitnessevalandassessment/a/FitnessTest.htm

Silverman, S., Keating, X. K., \& Philips, S. R. (2008). A Lasting Impression: A Pedagogical Perspective on Youth Fitness Testing. Measurement in Physical Education and Exercise Science, 12-20.

The Cooper Institute. (2007). FITNESSGRAM/ACTIVITYGRAM test administration manual (4th ed.). IL: Human Kinetics.

UPNM. (2010). Latar Belakang: UPNM. Retrieved November 14, 2012, from http://www.upnm.edu.my/index.php?req=7

UPNM. (2014). Laporan Tahunan 2013. Sungai Besi, Kuala Lumpur: Bahagian Kepimpinan Korporat dan Perhubungan Antarabangsa.

Zupan, M. F. (2012). Comparison of the 1.5 Mile Run Times at 7,200 Feet and Simulated 850 Feet in a Hyperoxic Room. United States Air Force Academy.

\section{Copyrights}

Copyright for this article is retained by the author(s), with first publication rights granted to the journal.

This is an open-access article distributed under the terms and conditions of the Creative Commons Attribution license (http://creativecommons.org/licenses/by/3.0/). 